\title{
KAJIAN AKTIVITAS ANTIOKSIDAN EKSTRAK DAUN TEMBELEKAN (Lantana camara L) BERDASARKAN TINGKAT KEPOLARAN PELARUT
}

\section{[Study of Antioxidant Activity of Tembelekan(Lantana camara L) Leaf Extract Based on Level Polar Solvent]}

\author{
Oktavian Mangela ${ }^{1 *}$, Ahmad Ridhay ${ }^{1)}$, Musafira $^{1)}$ \\ 1) Jurusan Kimia FMIPA Universitas Tadulako, Palu \\ J. Soekarno Hatta Km.9, Kampus Bumi Tadulako Tondo Palu, Telp. 0451- 422611
}

Diterima 7 Mei 2016, Disetujui 30 Juni 2016

\begin{abstract}
The investigation about the antioxidant activity of tembelekan (Lantana camara $L$ ) leaf extract based on level polar solvent. Has been done the aim of this study was to determine the $I_{C_{50}}$ value and to know the content of antioxidant compounds from tembelekan leaf extract based on the level of polar solvent the extraction of tembelekan leaf was done with maceration method. The result showed that ethyl acetate extract of tembelekan leaf has the highest antioxidant activity with $\mathrm{IC}_{50}$ value was 71,70 ppm.
\end{abstract}

Keywords: Tembelekan (Lantana Camara L ) , IC $C_{50}$, Antioxidant , DPPH

\begin{abstract}
ABSTRAK
Telah dilakukan penelitian tentang kajian aktivitas antioksidan ekstrak daun tembelekan (Lantana camara $L$ ) berdasarkan tingkat kepolaran pelarut. Tujuan penelitian ini adalah untuk mengetahui nilai $\mathrm{IC}_{50}$ dan mengetahui kandungan senyawa antioksidan dari ekstrak daun tembelekan berdasarkan tingkat kepolaran pelarut. Ekstraksi daun tembelekan dilakukan dengan menggunakan metode maserasi. Pengujian aktivitas antioksidan menggunakan metode DPPH. Hasil penelitian menunjukan bahwa ekstrak etil asetat daun Tembelekan memiliki aktivitas antioksidan tertinggi dengan nilai $\mathrm{IC}_{50}$ sebesar 71,70 .
\end{abstract}

Kata kunci: Tembelekan (Lantana Camara L) , IC 50 , Antioksidan, DPPH 


\section{LATAR BELAKANG}

Pengobatan secara tradisional umumnya menggunakan ramuan yang berasal dari tumbuhan, baik berupa akar, kulit batang, kayu, daun, bunga atau bijinya. Salin itu, ada pula yang berasal dari organ binatang dan bahan-bahan mineral. Agar supaya pengobatan tersebut dapat dipertanggung-jawabkan maka diperlukan penelitian-penelitian ilmiah seperti penelitian-penelitian dibidang farmakologi, toksikologi, identifikasi dan isolasi zat kimia aktif yang terdapat dalam tumbuhan.

Tumbuhan mengandung metabolit sekunder yang dapat berpotensi sebagai antioksidan, diantaranya adalah alkaloid, flavonoid, senyawa fenol, steroid, dan terpenoid (Marliana, 2007). Senyawa antioksidan dari tumbuhan dapat diperoleh dengan cara ekstrasi menggunakan pelarut. Perbedaan polaritas dari pelarut menghasilkan perbedaan jumlah dan jenis senyawa metabolit sekunder yang didapat (Fajarullah, 2014).

Penggunaan senyawa antioksidan semakin berkembang baik untuk makanan maupun untuk pengobatan seiring dengan bertambahnya pengetahuan tentang aktivitas radikal bebas (Boer, 2000). Stres oksidatif merupakan keadaan yang tidak seimbang antara jumlah molekul radikal bebas dan antioksidan di dalam tubuh (Trilaksani, 2003). Senyawa antioksidan merupakan suatu inhibitor yang digunakan untuk menghambat autooksidasi. Efek antioksidan senyawa fenolik dikarenakan sifat oksidasi yang berperan dalam menetralisasi radikal bebas (Panovska et al., 2005).

Tumbuhan tembelekan (Lantana camara $L$ ) digunakan masyarakat secara empiris untuk mengobati beberapa macam penyakit seperti batuk, luka, peluruh air seni, peluruh keringat, peluruh haid, penurun panas, obat bengkak, encok dan bisul (Mardisiswojo dan Mangunsudarso 1968). Tumbuhan tembelekan merupakan tanaman liar yang tumbuh tanpa perawatan khusus. Kandungan metabolit sekunder pada daun tembelekan seperti minyak atsiri, fenol, flavonoid, karbohidrat, protein, alkaloid, glikosida, glikosida iridoid, etanoid fenil, oligosakarida, quinin, saponin, steroid, terpenoid, sesquiterpenoid dan tanin dapat berpotensi sebagai antioksidan (Venkatachalam et al., 2011; Kensa, 2011; Bhakta and Ganewala, 2009).

Jenis pelarut yang digunakan dalam proses ekstraksi sampel yaitu etanol teknis, etil asetat teknis dan $n$-heksan teknis dan kloroform. Pelarut dipilih berdasarkan tingkat kepolaran yang berbeda dengan tujuan untuk memperoleh pelarut terbaik yaitu pelarut yang dapat mengekstrak dalam jumlah besar dan dapat mengekstrak golongan senyawa antioksidan yang mempunyai aktifitas tertinggi. Variasi pelarut perlu dilakukan karena senyawa aktif yang berpotensi sebagai antioksidan dalam daun tembelekan belum diketahui sifat kepolarannya. 
Berdasarkan latar belakang diatas, maka perlu dilakukan penelitian mengenai aktivitas antioksidan ekstrak daun tembelekan berdasarkan tingkat kepolaran pelarut.

\section{METODE PENELITIAN}

\section{Bahan dan Peralatan}

Bahan dasar yang digunakan dalam penelitian ini adalah daun tembelekan di ambil di kompleks perumahan jalan garuda Palu Sulawesi tengah. Bahan lain sebagai bahan pengekstrak dan bahan kimia untuk analisis yaitu $n$-heksan teknis, etil asetat teknis, etanol teknis, DPPH, $\mathrm{HCl}$ pekat, $\mathrm{FeCl}_{3} 5 \%$, pereaksi dragendorf, asam askorbat, serbuk magnesium, $\mathrm{H}_{2} \mathrm{SO}_{4}$ pekat anhidrida acetat, aquades, tissue, kertas saring dan aluminium foil.

Peralatan yang digunakan terdiri atas : Blender, Ayakan 60 mesh, talam aluminium, neraca analitik, rotari vakum evaporator, inkubator, alat penyaring vakum, Spektrofotometer UV-VIS, erlenmeyer, gelas kimia, kuvet, rak dan tabung reaksi, gelas kimia, gelas ukur, labu ukur, pipet tetes, corong kaca, cawan petri, sendok zat, pipet volum, dan botol reagen

\section{Prosedur Penelitian}

Penelitian ini dilaksanakan dalam tiga tahapan yaitu tahap pengolahan daun tembelekan, tahap ekstraksi daun tembelekan dengan metode maserasi,tahap identifikasi dan analisis uji aktivitas antioksidan.

\section{Tahap Pengolahan Daun Tembelekan}

Daun tembelekan dipisahkan dari tangkainya, kemudian dikering anginkan, lalu dihaluskan dengan blender dan diayak dengan ayakan 60 mesh untuk mendapatkan dau tembelekan dalam bentuk tepung. Tepung daun tembelekan disimpan untuk digunakan pada penelitian selanjutnya.

Tahap Ekstraksi Daun Tembelekan dengan Metode Maserasi (Lisnawati, 2014)

Ekstraksi dilakukan menggunakan metode maserasi dengan menggunakan tiga jenis pelarut. Ekstraksi pertama digunakan pelarut non polar yakni $n$ heksan dengan cara menimbang tepung daun tembelekan sebanyak $100 \mathrm{gr}$ kemudian dimasukkan kedalam erlenmeyer $1000 \mathrm{ml}$ lalu ditambahkan $1000 \mathrm{ml}$ nheksan. Campuran disimpan selama 2 x 24 jam sambil sesekali diaduk, kemudian disaring menggunakan corong buchner dan di rotari evaporator sehingga didapatkan ekstrak kental daun tembelekan, sedangkan residu yang diperoleh dikeringanginkan dan selanjutnya dimasukan ke dalam erlenmeyer untuk diekstrak kembali dengan pelarut etil asetat, kemudian pelarut etanol dengan perlakuan yang sama.

\section{Uji Golongan Senyawa}

\section{a. Uji flavonoid (Harborne, 1987)}

Ke dalam 1,0 ml larutan sampel ditambahkan sedikit serbuk magnesium dan beberapa tetes $\mathrm{HCl}$ pekat (pereaksi 
shinoda), bila bereaksi positif akan menghasilkan larutan berwarna jingga, merah muda atau merah.

\section{b. Uji polifenol dan tannin}

Ke dalam 1,0 ml sampel ditambahkan beberapa tetes larutan $\mathrm{FeCl}_{3} 5 \%$, bila bereaksi positif akan menghasilkan menghasilkan, merah, biru atau hijau kehitaman .

\section{c. Uji alkaloid}

Ke dalam 1,0 ml sampel ditambahkan beberapa 2-3 tetes pereaksi dragendorf, bila bereaksi positif akan menghasilkan endapan jingga.

\section{d. Uji Steroid / Triterpenoid}

Ke dalam $1 \mathrm{ml}$ sampel ditambahkan 2-3 tetes kloroform lalu ditambahkan anhidrida asam asetat dan 5 tetes asam sulfat pekat, bila bereaksi positif akan menghasilkan larutan berwarna biru atau hijau.Sedangkan untuk terpenoid menghasilakn larutan berwarna merah atau ungu

\section{Uji aktivitas Antioksidan dengan metode DPPH (Andayani dkk, 2012)}

Pada tahap ini, ekstrak pekat daun tembelekan yang diperoleh dari ketiga fraksi ( $n$-heksan, etil asetat, etanol dan) diuji aktifitas antiosidannya dengan cara ditimbang filtrat sebanyak $25 \mathrm{mg}$ dalam labu ukur $25 \mathrm{ml}$, kemudian dilarutkan dengan etanol, dan ditepatkan volumenya sehingga didapatkan konsentrasi $1 \mathrm{mg} / \mathrm{ml}$. Kemudian lakukan pengenceran dengan menambahkan etanol sehingga diperoleh sampel dengan konsentrasi $(10,30,50,70$, 90 ppm) Untuk penentuan aktivitas antioksidan masing-masing konsentrasi dipipet sebanyak $0,2 \mathrm{ml}$ larutan sampel dengan pipet mikro dan masukan ke dalam vial, kemudian tambahkan $3,8 \mathrm{ml}$ larutan DPPH $50 \mu \mathrm{M}$. Campuran dihomogenkan dan dibiarkan selama 30 menit ditempat gelap, serapan diukur dengan spektrofotometer UV - Vis pada panjang gelombang $517 \mathrm{~nm}$. Sebagai pembanding digunakan asam askorbat (konsentrasi 2,3,4,5,6 ppm) dengan perlakuan yang sama dengan sampel uji. Aktivitas antioksidan sampel ditentukan oleh besarnya hambatan serapan radikal DPPH melalui perhitungan persentase inhibisi serapan DPPH dengan menggunakan rumus :

$$
\% \text { Inhibisi }=\frac{\text { Abs. Kontrol }- \text { Abs. Sampel }}{\text { Abs. Kontrol }} \times 100 \%
$$

Ket: Abs. Kontrol = Absorban DPPH $50 \mu \mathrm{M}$ Abs. Sampel $=$ Absorbansi Sampel Uji

Nilai $I_{50}$ masing-masing konsentrasi sampel dihitung dengan menggunakan rumus persamaan regresi linier. $I_{50}$ adalah bilangan yang menunjukkan konsentrasi ekstrak yang mampu menghambat aktivitas suatu radikal sebesar $50 \%$ Untuk menentukan $\mathrm{IC}_{50}$, diperlukan persamaan kurva standar dari $\%$ inhibisi sebagai sumbu y dan konsentrasi fraksi antioksidan sebagai sumbu $\mathrm{x} . \quad \mathrm{IC}_{50}$ dihitung dengan cara memasukkan nilai $50 \%$ ke dalam persamaan kurva standar sebagai sumbu y kemudian dihitung nilai $\mathrm{x}$ sebagai konsentrasi $I_{50}$ 


\section{HASIL DAN PEMBAHASAN}

Hasil Estraksi Sampel dan Pengujian Golongan Senyawa Ekstrak Daun Tembelekan

Ekstrak daun tembelekan yang dihasilkan pada awal ekstraksi dilihat dari warna untuk $n$-heksan berwarna kuning, kemudian pada etil asetat dan etanol berwarna hijau. Pada proses maserasi digunakan variasi pelarut karena senyawa aktif dalam daun tembelekan belum diketahui sifat kepolarannya. Selain itu dengan adanya variasi pelarut diharapkan mendapatkan golongan senyawa aktif yang bervariasi pula pada tiap ekstraknya.

Ekstrak daun tembelekan yang diperoleh dari proses maserasi disaring dengan corong Buchner. Filtrat daun tembelekan lalu dipekatkan dengan rotary evaporator vacum untuk mendapatkan ekstrak yang pekat. Selanjutnya residu dari ekstrak $n$-heksan dimaserasi dengan etil asetat dan di evaporasi mendapatkan ekstrak etil asetat selanjutnya residunya di maserasi lagi dengan etanol dan diperoleh ekstrak kental dari etanol.

Hasil akhir yang diperoleh untuk ekstrak pekat daun tembelekan fraksi $n$ heksan berwarna kuning, sedangkan untuk etil asetat dan etanol berwarna hijau. Setelah di dapatkan hasilnya kemudian masing masing ekstrak di uji golongannya masing masing.Analisis golongan senyawa ekstrak daun tembelekan dari ketiga jenis pelarut dapat dilihat pada Tabel 1.
Tabel 1. Hasil Analisis Golongan Senyawa Ekstrak Daun Tembelekan Dari Ketiga Jenis Pelarut

\begin{tabular}{|c|c|c|c|}
\hline \multirow{2}{*}{$\begin{array}{c}\text { Golongan } \\
\text { senyawa }\end{array}$} & \multicolumn{3}{|c|}{ Jenis Pelarut } \\
\cline { 2 - 4 } & $n$-heksan & $\begin{array}{c}\text { Etil } \\
\text { asetat }\end{array}$ & Etanol \\
\hline Flavonoid & - & - & - \\
\hline Alkaloid & + & - & - \\
\hline $\begin{array}{c}\text { Polifenol/ } \\
\text { Tanin }\end{array}$ & - & + & + \\
\hline Steroid & - & + & - \\
\hline Terpenoid & + & - & - \\
\hline
\end{tabular}

Pengujian golongan senyawa ini bertujuan untuk mengetahui kandungan senyawa metabolit apa saja yang terdapat pada daun tembelekan. Uji kualitatif terhadap fraksi $n$-heksan dengan menggunakan pereaksi dragendorf dan pereaksi Lieberman-Burchard menunjukkan hasil positif terhadap keberadaan golongan Alkaloid dan terpenoid ditandai dengan perubahan warna menjadi jingga untuk alkaloid dan berwarna merah untuk terpenoid.

Fraksi etil asetat menggunakan pereaksi $\mathrm{FeCl}_{3} \quad 5 \%$ dan pereaksi Lieberman-Burchard menunjukkan hasil positif terhadap keberadaan tannin dan steroid ditandai dengan perubahan warna menjadi hijau kehitaman untuk tannin dan berwarna hijau untuk steroid. Fraksi etanol terdapat tanin setelah ditetesi pereaksi $\mathrm{FeCl}_{3} 5 \%$ dengan perubahan warna menjadi hijau kehitaman

\section{Hasil pengujian aktivitas Antioksidan dengan menggunakan metode DPPH}

Pengujian aktivitas antioksidan daun tembelekan dilakukan melalui penentuan 
$\%$ inhibisi fraksi $n$-heksan, etil asetat dan etanol pada masing - masing konsentrasi yaitu 10 ppm, 30 ppm, 50 ppm, 70 ppm, dan 90 ppm.

Aktivitas antioksidan $\left(\mathrm{IC}_{50}\right)$ pada masing - masing ekstrak dengan pelarut $n$ heksan (Gambar 1), etil asetat (Gambar 2), dan etanol (Gambar 3) ditentukan dengan menggunakan persamaan regresi linier dari kurva hubungan konsentrasi sampel terhadap persen inhibisi.

Persen inhibisi tertinggi dari pelarut $n$ heksan, etil asetat dan etanol dari data tabel dan kurva diatas yaitu sebesar; 34.535, 59.048 dan 51.382. Sedangkan nilai $I_{50}$ secara berturut - turut untuk pelarut $n$-heksan, etil asetat dan Etanol adalah :153.78 ppm ; 71,70 ppm dan 80,96 ppm.

Nilai $I_{50}$ diperoleh dari data \% Inhibisi yang diperoleh pada masing - masing pelarut dengan cara memasukkan nilai hasil perhitungan ke dalam persamaan linear dengan konsentrasi (ppm) sebagai absis $(X)$ dan nilai persentase inhibisi sebagai ordinat $(Y)$, nilai $I_{50}$ dari perhitungan pada saat \% inhibisi sebesar $50 \%$ dengan persamaan $Y=a X+b$.

Ekstrak etil asetat mempunyai aktivitas antioksidan yang lebih kuat dibandingkan dengan ekstrak $n$-heksan dan etanol, hal ini diduga karena adanya kandungan senyawa aktif dari beberapa golongan senyawa antioksidan yang bersifat semipolar yang terdapat dalam daun tembelekan.

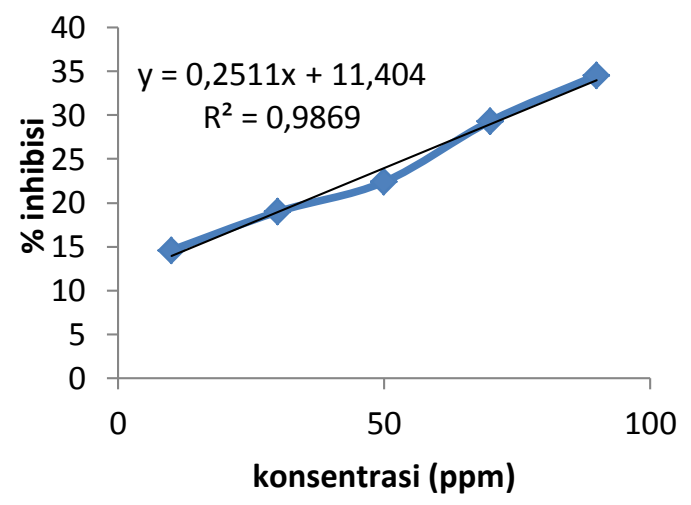

Gambar 1 Kurva Hubungan konsentrasi (ppm) ekstrak $n$-heksan dengan persentase inhibisi (\%).

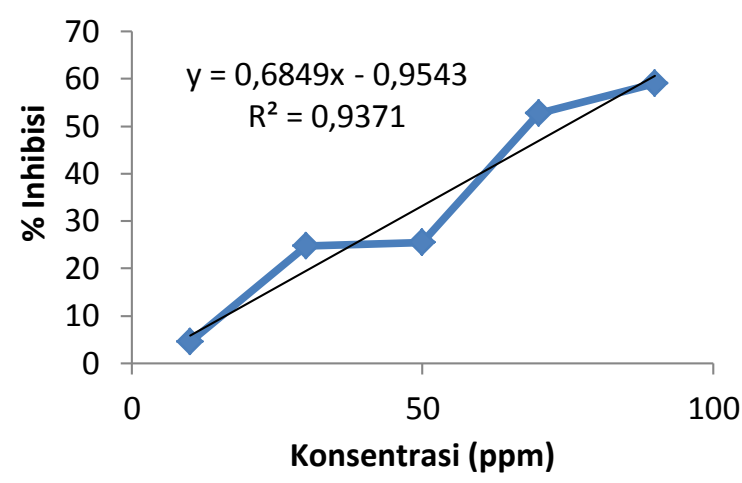

Gambar 2 Kurva Hubungan konsentrasi (ppm) ekstrak etil asetat dengan persentase inhibisi (\%)

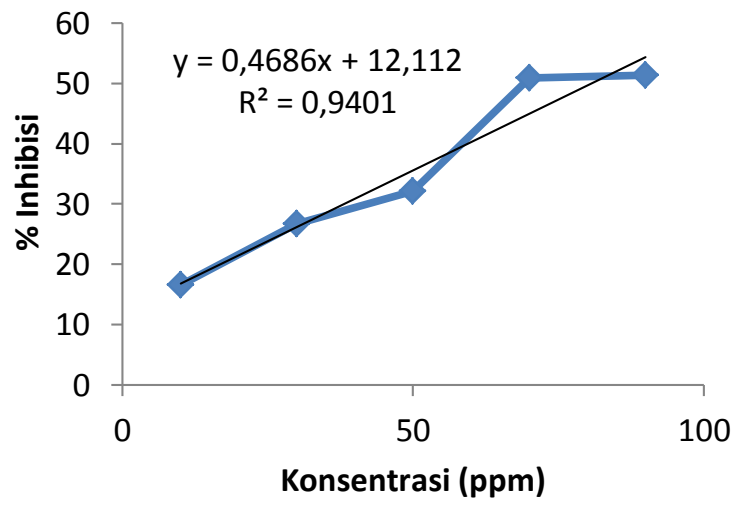

Gambar 3 Kurva Hubungan konsentrasi (ppm) ekstrak etanol dengan persentase inhibisi (\%).

Dari data diatas dapat diketahui bahwa semua fraksi ekstrak memiliki aktivitas antioksidannya masing masing baik dari pelarut polar, semipolar maupun non polar. Perbedaan aktivitas antioksidan ekstrak 
tersebut kemungkinan disebabkan oleh adanya perbedaan jumlah kandungan senyawa aktif yang terdapat dalam ekstrak, sehingga aktivitas antioksidannya dalam menangkap radikal bebas hasilnya juga berbeda. Fraksi yang memiliki nilai aktivitas antioksidan tertinggi adalah Etil asetat diikuti oleh Etanol dan $n$-heksan.

Adapun sebagai pembanding, dilakukan pengujian aktivitas antioksidan terhadap asam askorbat (Vitamin C) dengan masing - masing konsentrasi 2, 3, 4, 5 dan 6 ppm. Untuk nilai $\left(\mathrm{IC}_{50}\right)$ pada asam askorbat dapat ditentukan dengan menggunakan persamaan regresi linier dari kurva hubungan konsentrasi sampel terhadap persen inhibisi. Dapat dilihat pada gambar 4 di bawah ini :

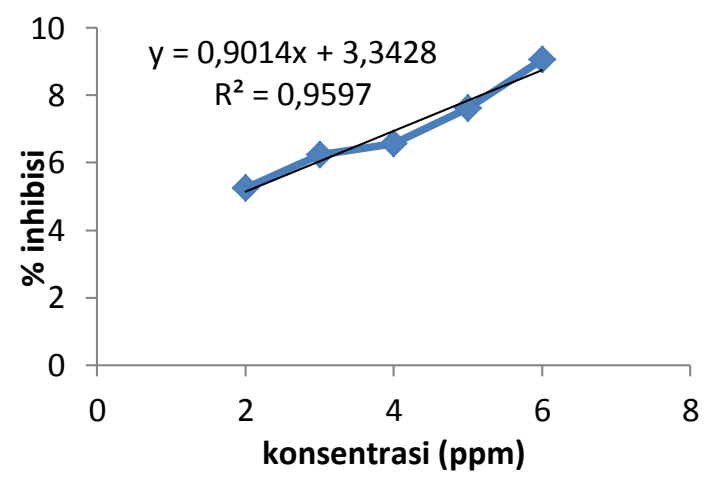

Gambar 4 Kurva hubungan konsentrasi (ppm) asam askorbat dengan persentase inhibisi (\%)

Berdasarkan kurva diatas, nilai persen Inhibisi tertinggi untuk asam askorbat adalah 9,013. Nilai $I_{50}$ asam askorbat adalah 51,78 ppm. Dibandingkan dengan etil asetat, etanol dan $n$-heksan nilai $I_{50}$ asam askorbat masih lebih bagus.

Penggunaan jenis pelarut yang berbeda berpengaruh terhadap aktivitas antioksidan (Lestario (2001) dalam
Lisnawati (2014) menyatakan bahwa penggunaan pelarut yang berbeda tingkat kepolaran mempengaruhi jenis senyawa yang terekstrak.

Menurut Fatimah (2008) Semakin kecil nilai $I_{50}$ berarti semakin tinggi aktivitas antioksidan dan suatu senyawa dikatakan sebagai antioksidan sangat kuat jika nilai $I C_{50}$ kurang dari 50 ppm, kuat untuk $I_{50}$ bernilai $50-100$ ppm, sedang jika bernilai 100-150 ppm, dan lemah jika nilai $I_{50}$ bernilai 150-200 ppm sangat lemah jika nilai $I_{50}$ bernilai 200-1000 ppm.

Hasil penelitian mengenai Penapisan fraksi antioksidan daun buas buas (Premna serratifolia Linn) di peroleh Nilai $\mathrm{IC}_{50}$ fraksi $n$-heksana, kloroform, dan metanol adalah 15,2240 ppm, 8,7729 ppm, dan 20,3418 ppm (Oktaviani , 2015).

Penelitian lain oleh Huliselan dkk. (2015) terhadap aktivitas antioksidan ekstrak etanol, etil asetat dan $n$-heksan dari daun sesewanua (Clerodendron squamatum V.) menunjukkan fraksi etil asetat memiliki aktivitas antioksidan tertinggi dengan nilai $I_{50}$ sebesar 13,084 ppm, diikuti ekstrak etanol sebesar 17,85 ppm, dan ekstrak $n$ heksan sebesar 23,737 ppm.

\section{KESIMPULAN}

Aktivitas antioksidan $\left(\mathrm{IC}_{50}\right)$ daun tembelekanuntuk ekstrak $n$ - heksan, etil asetat dan etanol masing - masing adalah 153.78 ppm, 71.70 ppm dan 80.96 ppm. Aktivitas antioksidan $\left(\mathrm{IC}_{50}\right)$ Daun tembelekan pada ekstrak $n$-heksan bersifat lemah, sedangkan pada ekstrak etil asetat 
dan etanol bersifat kuat. Kandungan senyawa pada daun tembelekan pada ekstrak $n$-heksan terdapat alkaloid dan terpenoid, pada ekstrak etil asetat terdapat polifenol/tanin dan steroid sedangkan pada etanol terdapat polifenol/tannin.

\section{DAFTAR PUSTAKA}

Andayani R., Maimunah dan Lisawati Y, 2012. Penetuan Aktivitas Antioksidan, Kadar Fenolat Total dan Likoepen Pada Buah Tomat(Solanm Lycopersicum L). [Skripsi]. Padang: Universitas Andalas.

Boer. Y. 2000. Uji Aktivitas Antioksidan Ekstrak Kulit Buah Kandis (Garcinia parvifolia Miq). Jurnal Matematika dan IPA 1. (1): 26-33

Bhakta D., Ganjewala D. 2013 Effect of leaf positions on total phenolics, Flavonoids and proantho-Agustus, cyanidins content and antioxidant activities in Lantana camara (L). Journal of Scientific Research. 1 (2): 363-369.

Fatimah C. 2008. Aktivitas antioksidan Senyawa Flavonoid dari Daun Katuk (Sauropus androgunusL Merr). Jurnal Biologi- USU. 3 (1): 7-9.

Fajarullah, A.2014. Ekstraksi Senyawa Metabolit Sekunder Lamun Thalassodendron ciliatum Pada Pelarut Berbeda [skripsi]. Tanjung Pinang: Universitas Maritim

Harborne J B. 1987. Metode Fitokimia: penuntun cara modern menganalisis tumbuhan. Ed. II. Diterjemahkan oleh Padmawinata K, Sudiro I. Bandung: Institut Teknologi Bandung. 3-15.

Kensa V.M. 2011. Studies on phytochemical screening and Antibacterial activities of Lantana camara Linn. Plant Sciences Feed., 1 (5): 74-79.

Lisnawati. 2014. Aktivitas antioksidan ekstrak daun kelor dari berbagai jenis pelarut. [Skripsi]. Palu: Fakultas MIPA Universitas Tadulako.

Mardisiswojo.S., Radjak mangunsudarso, H. 1968. Cabe puyang warisan nenek moyang III. Jakarta: P.T. Karya Wreda

Marliana, E. 2007. Analisis Senyawa Metabolit Sekunder dari Batang Spatholobus ferrugineus (Zoll \& Moritzi) benth yang berfungsi sebagai antioksidan. Penelitian Mipa.1:23-25.

Oktaviani E. 2015. Penapisan fraksi Antioksidan Daun Buas buas (Premna serratifolia Linn) Pontianak : Program Studi Kimia Fakultas MIPA UniversitasTanjungpura

Panovska. T.K. Kulevanova. S. Stefova. 2005. In Vitro Antioxidant Activity of Some Teucrium Spesies (Lamiaceae). Acta Pharm. 55 : 207214

Trilaksani. W. 2003, Antioksidan: Jenis, Sumber, Mekanisme Kerja dan Peran Terhadap Kesehatan. Bogor: Institute Pertanian Bogor, 1-12.

Venkatachalam T. Kumar VK. Selvi PK. Maske AO. Kumar NS 2011. Physicochemical and preliminary phytochemical studies on the Lantana Camara L.) fruits. International Journal Of Pharmacy and Pharmaceutical Sciences. 3 (1): 52-54.

Huliselan YM., Runtuwene MRJ., Wewengkang DS. 2015. Aktivitas Antioksidan Ekstrak Etanol, Etil asetat dan $n$-heksan Dari Daun Sesewanua (Clerodendron squamatum V.) Jurnal IImiah Farmasi- UNSRAT. 4(3): 155-163. 